\title{
Differential Toxicity of Some Insecticides Against Egg and Larval Stages of Cotton Leafworm and Role of Two Detoxification Enzymes
}

\author{
Hamdy K. Abou-Taleb ${ }^{1}$
}

\begin{abstract}
Toxicity of some insecticides against egg masses and two larval instars of cotton leafworm (CLW), Spodoptera littoralis, field and laboratory strains was determined. The activities of glutathione $S$-transferases (GST) and alkaline phosphatases (ALP) in the two strains also were compared. Results revealed that, spinosad, spinetoram, emamectin benzoate and lufenuron have low ovicidal activity. Chlorpyrifos and methomyl at $10 \mathrm{ppm}$ achieved 80.4 and 83.6\% mortality of treated egg masses, respectively. On the other hand, spinosad, spinetoram and emamectin benzoate at the same concentration caused $18.9,19.4$ and $28.1 \%$ mortality of treated egg masses, respectively. While lufenuron at 25 ppm caused $54.9 \%$ mortality of treated egg masses, lufenuron at $100 \mathrm{ppm}$ achieved $100 \%$ mortality of treated egg masses at $100 \mathrm{ppm}$. Although spinosad, spinetoram and emamectin benzoate have low ovicidal activity compared with methomyl and chlorpyrifos, they have a comparable residual toxicity with methomyl and chlorpyrifos against the neonates. The residual toxicity of lufenuron against neonates is low at all tested concentrations. The $2^{\text {nd }}$ and $4^{\text {th }}$ instar larvae of the field strain exerts high resistance levels towards methomyl, chlorpyrifos and esfenvalerate. Regarding the $2^{\text {nd }}$ instar, resistance ratios in 2008 and 2009 cotton seasons were 43.9 and 50.8 towards methomyl, 27.6 and 24.7 towards chlorpyrifos and 76.4 and 79.2 towards esfenvalerate. For the $4^{\text {th }}$ instar resistance ratios in 2008 and 2009 cotton seasons were 62.8 and 63.6 towards methomyl, 43.9 and 49.2 towards chlorpyrifos and 112.4 and 114.8 towards esfenvalerate. On the other hand, field strain shows low or no levels of tolerance to spinosad, spinetoram, emamectin benzoate, lufenuron and methoxyfenozide. Activities of GST and ALP in the field strain were higher compared with that in the laboratory strain. In conclusion, the alternation between these insecticides can avoid increasing selection pressure of CLW populations to these insecticides.
\end{abstract}

\section{INTRODUCTION}

Cotton leafworm (CLW), Spodoptera littoralis, is one of the most destructive agricultural lepidopterous pests. It can attack numerous economically important crops all the year round. The chemical control of $S$. littoralis has been extensively reported in relation especially to cotton in Egypt (Issa et al., 1984a \& b and Abo Elghar et al., 1986). Extensive use of insecticides, multiple generations of CLW per annum, and the availability of host crops, around the year, have contributed to the development of resistance in this pest to many insecticide groups (Abo Elghar et al., 2005).

In Egypt, management of CLW has depended on preserving and extending the insecticide efficacy based on rotating various insecticides including organophosphates, carbamates, insect growth regulators, and pyrethroids every year (Temerak, 2002). In addition, the continuous monitoring of resistance is fundamentally important to every resistance management program (Prabhaker et al., 1996). At the same time, searching for an effective alternatives and/or pest control strategies to avoid increasing selection pressure of the insect population to insecticides is so important. More consideration needs also to be given to the possibility of controlling the pest at other stages of its development, when it may be more susceptible to the chemicals used for control. Several studies had been conducted to evaluate the ovicidal activity against many insect species (Wells and Guyer, 1962; Dittrich, 1967; Mitri and Kamel, 1970; El-Guindy et al., 1983; Renkleff et al., 1995; Canela et al., 2000).

Different mechanisms of resistance to organophosphate, carbamate and pyrethroid insecticides have been identified in CLW, including enhanced metabolism, nerve insensitivity, reduced penetration and target site insensitivity (Attia, 1999; Abo Elghar et al., 2005). Among the metabolic enzymes are glutathione $S$ transferase (GST) and alkaline phosphatase (ALP). Glutathione $S$-transferases are enzymes widespread in both prokaryotic and eukaryotic cells and catalyze the glutathione conjugation reaction with reduced glutathione (GSH) (Listowsky et al., 1998; Armstrong, 1997). Phosphatases have been included in the list of detoxifying enzymes of insecticides; mostly of organophosphorus (Oppenoorth, 1985).

Therefore, the present study investigated the susceptibility of CLW field strain (collected from AbouEl-Matameer city) compared with the laboratory strain to selected insecticides of diverse chemistries. Also, the activities of GST and ALP in both strains were investigated. In addition, the ovicidal activity of some insecticides was carried out.

${ }^{1}$ Plant Protection Research Institute, ARC, Bacous, Sabahia, Alexandria Egypt.

Received November 9, 2010, Accepted December 22, 2010. 


\section{MATERIALS AND METHODS}

\section{Experimental insect:}

a. Laboratory strain: Cotton leafworm, Spodoptera littoralis, larvae used for testing program was obtained from Plant Protection Research Institute and reared in the laboratory on castor bean leaves in 1-liter muslin covered mason jars. The number of larvae per jar differed according to the larval instar. All larvae were transferred every day into clean disinfected jars containing fresh food and the numbers adjusted according to the larval instar. When the larvae pupated they were sexed and 12 pupae put into each jar. When the moths emerged they were supplied with a piece of cotton moistened with $10 \%$ sugar solution and 2 Nerium oleander leaves, on which they deposited their eggs. The egg masses were collected daily and as they hatched on the oleander leaves the larvae were transferred to fresh castor oil leaves. The colony was kept at a temperature of $25 \pm 2{ }^{\circ} \mathrm{C}$ and $65 \pm 5 \% \mathrm{RH}$ (Eldefrawi et al., 1964).

b. Field strain: Cotton leafworm egg masses were collected from cotton fields of Abou-El-Matameer city, El-Behera governorate during 2008 \& 2009 cotton seasons and transferred to the laboratory. The resulting larvae for test purposes were reared in the laboratory on castor bean leaves at a temperature of $25 \pm 2{ }^{\circ} \mathrm{C}$ and $65 \pm 5$ $\%$ RH.

Tested insecticides: Emamectin benzoate (Proclaim $^{\circledR}$ $5 \% \mathrm{SG}$ ) and lufenuron (Match ${ }^{\circledR}$ 5\%EC) were supplied by Syngenta. Chlorpyrifos (Dursban 48\%EC), spinosad (Tracer $^{\circledR} 24 \%$ SC), spinetoram (Radiant ${ }^{\circledR} 12 \%$ SC) and methoxyfenozide (Runner ${ }^{\circledR} 24 \%$ SC) were supplied by Dow Agrosciences Co. Esfenvalerate (SumiGold $20 \%$ EC) was supplied by Sumitomo Chemical Co. Ltd. Methomyl (Lannate 90\% SL) was supplied by E. I. du Pont de Nemours \& Co.

Ovicidal activity: Ovicidal activity of the formulated spinosad, spinetoram, chlorpyrifos, emamectin benzoate, methomyl, and lufenuron against the laboratory strain of $S$. littoralis egg masses was determined. The upper layers of each egg mass (0-24 hr old) were removed gently with a fine hair brush. The lower layer in each egg mass was counted by the binocular. The counted egg samples were dipped (5 seconds) in different concentrations of the tested compounds, while the control was dipped in water according to Dittrich (1967). Each treatment was replicated three times. Treatments and control were held in a plastic cups $(9 \mathrm{x} 4$ $\mathrm{cm})$ at $27 \pm 2{ }^{\circ} \mathrm{C}, 65-75 \% \mathrm{RH}$ and observed until hatching. The number of un-hatched eggs, dead neonates and live larvae were counted, and the mortality percentages were calculated.
Bioassay studies: Toxicity of the formulated insecticides against $2^{\text {nd }}$ and $4^{\text {th }}$ instar larvae of $S$. littoralis (Laboratory and field strains) was evaluated. Homogenous pieces of the castor oil leaves were dipped in a series of each insecticide concentrations for $10 \mathrm{sec}$., held vertically to allow excess solution to drip off and dried at room temperature. Treated castor oil leaf pieces were transferred to a plastic cups, and the appropriate number and weight of starved larvae were added. Each concentration was replicated four times. Mortality percentages were recorded after $24 \mathrm{hrs}$ of treatment for chlorpyrifos, spinosad, spinetoram, esfenvalerate \& methomyl and after 72 hrs for emamectin benzoate, lufenuron and methoxyfenozide. Mortality percentages were corrected according to Abbott equation (Abbott, 1925) and subjected to probit analysis (Finney, 1971).

Assay of GST activity of the $2^{\text {nd }}$ and $4^{\text {th }}$ instar larvae (Lab. and field strains): Preparation of GST: Total larvae of the $2^{\text {nd }}$ instar and the collected midguts of the $4^{\text {th }}$ instar larvae were rinsed in ice-cold $100 \mathrm{mM}$ phosphate buffer $\mathrm{pH} 7$ and homogenized in glass homogenizer $(1: 10 \mathrm{w} / \mathrm{v})$ in the same buffer. The homogenate was centrifuged at $14,000 \mathrm{rpm}$ for $30 \mathrm{~min}$ at $4^{\circ} \mathrm{C}$ using Cryofuge 20-3, Heraeus Christ centrifuge. The supernatant was served as the enzyme source.

Enzyme assay: Glutathione $S$-transferases activity was measured according to the method of Asaoka and Takahashi (1983) using ethanolic solution of $O$ dinitrobenzene (DNB) as a substrate with slight modification (El-Shahawi and Al-Rajhi, 2000). The standard assay mixture $(1 \mathrm{ml})$ contained: $1.5 \mathrm{mM}$ reduced glutathione (GSH), $100 \mathrm{mM}$ phosphate buffer

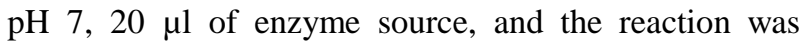
started by the addition of $0.5 \mathrm{mM}$ DNB. After incubation at $37^{\circ} \mathrm{C}$ for $20 \mathrm{~min}$, the reaction was terminated by the addition of $0.1 \mathrm{ml}$ acetic anhydride. The mixture was left for $5 \mathrm{~min}$ at room temperature, and then mixed with $1 \mathrm{ml}$ of $1 \%(\mathrm{w} / \mathrm{v})$ sulfanilamide in $20 \%(\mathrm{w} / \mathrm{v}) \mathrm{HCl}$ followed by $1 \mathrm{ml}$ of $0.02 \%(\mathrm{w} / \mathrm{v}) \mathrm{N}-(1$-naphthyl) ethylenediamine dihydrochloride. After diazo-coupling for $20 \mathrm{~min}$ at room temperature, $0.1 \mathrm{ml}$ of $1 \%(\mathrm{w} / \mathrm{v})$ ammonium sulfamate (freshly prepared) was added to the mixture. The mixture was left for $5 \mathrm{~min}$, and then the absorbance at $540 \mathrm{~nm}$ was recorded using spectrophotometer (Milton Roy Spectronic 601). An assay mixture without enzyme was used as the blank. GST specific activity was calculated as $\mathrm{OD} / \mathrm{mg}$ protein/min.

Assay of ALP activity of the $2^{\text {nd }}$ and $4^{\text {th }}$ instar larvae (Lab. and field strains): Preparation of ALP: Total larvae of the $2^{\text {nd }}$ instar and the collected midguts of the $4^{\text {th }}$ instar larvae were homogenized (1: $\left.10 \mathrm{w} / \mathrm{v}\right)$ in 100 $\mathrm{mM}$ phosphate buffer $\mathrm{pH} 9.8$, using glass homogenizer. The homogenate was centrifuged at $5000 \mathrm{rpm}$ for $30 \mathrm{~min}$ 
at $4^{\circ} \mathrm{C}$ using IEC-CRU 5000 cooling centrifuge. The supernatant was used for ALP activity estimation.

Enzyme assay: Activity of ALP was determined according to the method of Dgkc (1972), using Diamond Diagnostic kit (Diamond Co. Egypt). In this method 20 $\mu \mathrm{l}$ of the enzyme source was added to $1 \mathrm{ml}$ of $0.9 \mathrm{M}$ diethanolamine buffer $\mathrm{pH} 9.8$ containing $0.6 \mathrm{mM}$ magnesium ions and $1 \mathrm{mM}$ p-nitrophenyl phosphate, then mix in the cuvette, incubate for 30 seconds in the spectrophotometer (Milton Roy Spectronic 601), start stopwatch simultaneously and read again after exactly 1 , 2 and 3 minutes at $405 \mathrm{~nm}$. ALP specific activity was calculated as IU/mg protein/min.

Protein measurements: Protein estimation has been carried out according to Lowery et al., (1951).

\section{RESULTS AND DISCUSSION}

Ovicidal activity of tested insecticides against CLW egg masses:

One of our objectives in this study was to evaluate the ovicidal activity of some insecticides against 0-1 day old egg masses of CLW. Some insecticides may be more efficient as ovicides than larvicides. The residual toxicity of these insecticides to the new hatched neonates was also determined. Data in Table(1) showed that, spinosad, spinetoram, emamectin benzoate and lufenuron have low ovicidal activity compared with both chlorpyrifos and methomyl. Chlorpyrifos and methomyl at $10 \mathrm{ppm}$ achieved 80.4 and $83.6 \%$ mortality of treated egg masses, respectively. On the other hand, spinosad, spinetoram and emamectin benzoate at the same

Table 1. Ovicidal and residual toxicity of some insecticides against Spodoptera (Lab. strain) egg masses

\begin{tabular}{|c|c|c|c|c|c|}
\hline \multirow[t]{2}{*}{ Insecticide } & \multirow{2}{*}{$\begin{array}{l}\text { Conc. } \\
\text { (ppm) }\end{array}$} & \multirow{2}{*}{$\begin{array}{l}\text { No. treated } \\
\text { eggs }\end{array}$} & \multicolumn{3}{|c|}{ \% Mortality 24 hrs after hatching \pm SD } \\
\hline & & & eggs & neonates & total \\
\hline \multirow[t]{5}{*}{ Spinosad } & 0.5 & 384 & $8.1 \pm 1.2$ & $20.1 \pm 2.7$ & $26.6 \pm 3.1$ \\
\hline & 1.0 & 411 & $14.7 \pm 2.5$ & $34.6 \pm 2.4$ & $44.3 \pm 5.3$ \\
\hline & 2.0 & 364 & $17.9 \pm 1.9$ & $52.8 \pm 5.6$ & $61.3 \pm 3.6$ \\
\hline & 5.0 & 344 & $19.7 \pm 2.1$ & $66.7 \pm 4.8$ & $73.8 \pm 6.4$ \\
\hline & 10.0 & 362 & $18.9 \pm 2.6$ & $92.5 \pm 3.7$ & $93.8 \pm 3.8$ \\
\hline \multirow[t]{5}{*}{ Spinetoram } & 0.5 & 350 & $4.8 \pm 0.8$ & $19.5 \pm 2.5$ & $23.5 \pm 2.6$ \\
\hline & 1.0 & 372 & $6.7 \pm 1.0$ & $45.2 \pm 5.0$ & $48.9 \pm 5.2$ \\
\hline & 2.0 & 324 & $10.1 \pm 1.4$ & $69.1 \pm 5.3$ & $72.3 \pm 6.4$ \\
\hline & 5.0 & 356 & $16.6 \pm 1.7$ & $89.9 \pm 4.0$ & $91.7 \pm 4.1$ \\
\hline & 10.0 & 342 & $19.4 \pm 2.0$ & $100.0 \pm 0.0$ & $100.0 \pm 0.0$ \\
\hline \multirow{5}{*}{$\begin{array}{c}\text { Emamectin } \\
\text { benzoate }\end{array}$} & 0.5 & 366 & $3.5 \pm 0.4$ & $28.9 \pm 3.2$ & $31.4 \pm 3.3$ \\
\hline & 1.0 & 402 & $12.7 \pm 1.1$ & $40.7 \pm 3.7$ & $48.3 \pm 5.0$ \\
\hline & 2.0 & 335 & $15.2 \pm 1.7$ & $66.5 \pm 6.3$ & $71.5 \pm 5.7$ \\
\hline & 5.0 & 337 & $20.9 \pm 2.1$ & $100.0 \pm 0.0$ & $100.0 \pm 0.0$ \\
\hline & 10.0 & 354 & $28.1 \pm 3.2$ & $100.0 \pm 0.0$ & $100.0 \pm 0.0$ \\
\hline \multirow[t]{5}{*}{ Methomyl } & 1.0 & 342 & $33.6 \pm 2.7$ & $11.0 \pm 1.8$ & $40.9 \pm 4.5$ \\
\hline & 5.0 & 351 & $54.1 \pm 3.7$ & $28.6 \pm 2.6$ & $67.3 \pm 6.3$ \\
\hline & 10.0 & 354 & $83.6 \pm 2.4$ & $86.2 \pm 5.1$ & $97.7 \pm 2.0$ \\
\hline & 15.0 & 327 & $95.4 \pm 1.8$ & $80.0 \pm 6.7$ & $99.1 \pm 0.2$ \\
\hline & 20.0 & 352 & $100.0 \pm 0.0$ & - & $100.0 \pm 0.0$ \\
\hline \multirow[t]{5}{*}{ Chlorpyrifos } & 1.0 & 390 & $20.2 \pm 2.4$ & $24.7 \pm 3.2$ & $40.0 \pm 4.3$ \\
\hline & 2.0 & 352 & $31.6 \pm 3.2$ & $52.9 \pm 4.3$ & $67.9 \pm 6.2$ \\
\hline & 5.0 & 341 & $54.8 \pm 3.9$ & $84.8 \pm 4.9$ & $93.3 \pm 4.7$ \\
\hline & 10.0 & 382 & $80.4 \pm 3.5$ & $100.0 \pm 0.0$ & $100.0 \pm 0.0$ \\
\hline & 15.0 & 348 & $89.6 \pm 4.1$ & $100.0 \pm 0.0$ & $100.0 \pm 0.0$ \\
\hline \multirow[t]{5}{*}{ Lufenuron } & 1.0 & 344 & $17.7 \pm 2.3$ & $2.5 \pm 0.2$ & $19.8 \pm 2.1$ \\
\hline & 5.0 & 356 & $37.6 \pm 4.2$ & $3.6 \pm 0.0$ & $39.9 \pm 4.8$ \\
\hline & 25.0 & 370 & $54.9 \pm 4.8$ & $5.1 \pm 0.7$ & $57.3 \pm 4.6$ \\
\hline & 50.0 & 360 & $83.6 \pm 4.4$ & $4.8 \pm 0.7$ & $84.4 \pm 5.8$ \\
\hline & 100.0 & 347 & $100.0 \pm 0.0$ & - & $100.0 \pm 0.0$ \\
\hline
\end{tabular}


concentration caused $18.9,19.4$ and $28.1 \%$ mortality of treated egg masses, respectively. Lufenuron at $25 \mathrm{ppm}$ caused $54.9 \%$ mortality of treated egg masses, while, mortality oftreated egg masses. Although spinosad, spinetoram and emamectin benzoate have low ovicidal activity compared with methomyl and chlorpyrifos, they have a comparable residual toxicity with methomyl and chlorpyrifos against the neonates. The residual toxicity of lufenuron against neonates is low at all tested concentrations.

In previous studies, Pinela et al. (2000) stated that treatment of $S$. littoralis $0-24 \mathrm{~h}$ eggs by spinosad at 10 mg a.i / litre or above caused $100 \%$ mortality of newly emerged larvae after the first day of hatching. When tobacco budworm eggs were treated with spinosad, only $49 \%$ egg mortality was observed. On the other hand, none of the tobacco budworm larvae that emerged survived (Bret et al., 1997). Also, Sherby et al., (2010) recorded 95.8 and $82.6 \%$ mortality of eggs and new hatched larvae by spinosad and chlorpyrifos at $10 \mathrm{ppm}$, respectively. Regarding lufenuron, although it is known that among the diverse actions of IGRs on the life cycles of insects are ovicidal and larvicidal effects (Ascher et al., 1987), it has a low ovicidal activity compared with methomyl and chlorpyrifos. In respect with emamectin benzoate (semi-synthetic of abamectin), Bueno and Freitas (2004) reported that abamectin has no effect on the Chrysoperla externa egg viability.

Toxicity of tested insecticides to $2^{\text {nd }}$ and $4^{\text {th }}$ instar larvae of field and laboratory strains of CLW:

Susceptibility of $2^{\text {nd }}$ and $4^{\text {th }}$-larval instars from the laboratory and field strains, collected during the cotton season of 2008 and 2009 to selected insecticides is presented in Tables (2 and 3).

Table 2. Median lethal concentrations of some insecticides against laboratory and field strains of Spodoptera littoralis $2^{\text {nd }}$ instar larvae

\begin{tabular}{|c|c|c|c|c|c|c|}
\hline Insecticide & Year & Strain & $\mathrm{LC}_{50}(\mathrm{ppm})$ & Confidence limits & Slope \pm SE & $\mathbf{R R}^{*}$ \\
\hline \multirow[t]{4}{*}{ Spinosad } & 2008 & Lab. & 37.2 & $28.7-47.5$ & $2.3 \pm 0.20$ & 1 \\
\hline & & Field & 63.7 & $52.1-78.8$ & $1.9 \pm 0.17$ & 1.7 \\
\hline & 2009 & Lab. & 35.8 & $29.6-43.9$ & $2.1 \pm 0.23$ & 1 \\
\hline & & Field & 68.4 & $53.0-88.8$ & $1.8 \pm 0.19$ & 1.9 \\
\hline \multirow[t]{4}{*}{ Spinetoram } & 2008 & Lab. & 12.3 & $8.5-17.2$ & $2.5 \pm 0.26$ & 1 \\
\hline & & Field & 28.7 & $23.9-35.1$ & $1.7 \pm 0.18$ & 2.3 \\
\hline & 2009 & Lab. & 11.9 & $8.0-16.3$ & $2.0 \pm 0.18$ & 1 \\
\hline & & Field & 26.4 & $20.8-33.2$ & $1.8 \pm 0.16$ & 2.2 \\
\hline \multirow{4}{*}{$\begin{array}{l}\text { Emamectin } \\
\text { benzoate }\end{array}$} & 2008 & Lab. & 0.002 & $0.0015-0.0027$ & $1.8 \pm 0.17$ & 1 \\
\hline & & Field & 0.007 & $0.006-0.009$ & $1.8 \pm 0.18$ & 3.5 \\
\hline & 2009 & Lab. & 0.002 & $0.0014-0.0026$ & $1.9 \pm 0.17$ & 1 \\
\hline & & Field & 0.008 & $0.006-0.011$ & $1.8 \pm 0.20$ & 4.0 \\
\hline \multirow[t]{4}{*}{ Methomyl } & 2008 & Lab. & 3.9 & $2.8-5.4$ & $2.6 \pm 0.27$ & 1 \\
\hline & & Field & 171.3 & $147.8-203.5$ & $1.6 \pm 0.18$ & 43.9 \\
\hline & 2009 & Lab. & 3.6 & $3.0-4.8$ & $2.9 \pm 0.22$ & 1 \\
\hline & & Field & 182.8 & $146.9-210.6$ & $1.8 \pm 0.19$ & 50.8 \\
\hline \multirow[t]{4}{*}{ Chlorpyrifos } & 2008 & Lab. & 2.7 & $2.4-3.2$ & $1.8 \pm 0.16$ & 1 \\
\hline & & Field & 74.6 & $58.1-94.9$ & $1.9 \pm 0.16$ & 27.6 \\
\hline & 2009 & Lab. & 2.9 & $2.4-3.6$ & $2.0 \pm 0.20$ & 1 \\
\hline & & Field & 71.7 & $63.2-81.5$ & $1.8 \pm 0.21$ & 24.7 \\
\hline \multirow[t]{4}{*}{ Esfenvalerate } & 2008 & Lab. & 0.5 & $0.44-0.58$ & $1.6 \pm 0.14$ & 1 \\
\hline & & Field & 38.2 & $30.6-48.5$ & $1.5 \pm 0.16$ & 76.4 \\
\hline & 2009 & Lab. & 0.5 & $0.44-0.58$ & $1.6 \pm 0.17$ & 1 \\
\hline & & Field & 39.6 & $31.9-51.8$ & $1.5 \pm 0.14$ & 79.2 \\
\hline \multirow[t]{4}{*}{ Lufenuron } & 2008 & Lab. & 2.3 & $1.8-3.0$ & $1.9 \pm 0.21$ & 1 \\
\hline & & Field & 15.6 & $11.6-21.4$ & $1.8 \pm 0.20$ & 6.8 \\
\hline & 2009 & Lab. & 2.0 & $1.6-2.6$ & $1.8 \pm 0.21$ & 1 \\
\hline & & Field & 17.3 & $12.8-23.6$ & $1.8 \pm 0.19$ & 8.7 \\
\hline \multirow[t]{4}{*}{ Methoxyfenozide } & 2008 & Lab. & 1.8 & $1.4-2.6$ & $2.4 \pm 0.25$ & 1 \\
\hline & & Field & 12.7 & $9.3-16.3$ & $2.3 \pm 0.22$ & 7.1 \\
\hline & 2009 & Lab. & 1.9 & $1.6-2.4$ & $2.5 \pm 0.23$ & 1 \\
\hline & & Field & 11.8 & $8.4-16.4$ & $2.2 \pm 0.20$ & 6.2 \\
\hline
\end{tabular}


Table 3. Median lethal concentrations of some insecticides against laboratory and field strains of Spodoptera littoralis $4^{\text {th }}$ instar larvae

\begin{tabular}{|c|c|c|c|c|c|c|}
\hline Insecticide & Year & Strain & $\mathrm{LC}_{50}(\mathrm{ppm})$ & Confidence limits & Slope \pm SE & $\mathbf{R R}^{*}$ \\
\hline \multirow[t]{4}{*}{ Spinosad } & 2008 & Lab. & 162.4 & $139.8-193.2$ & $1.9 \pm 0.21$ & 1 \\
\hline & & Field & 478.3 & $414.7-552.9$ & $1.6 \pm 0.18$ & 2.9 \\
\hline & 2009 & Lab. & 173.2 & $142.5-211.9$ & $1.9 \pm 0.22$ & 1 \\
\hline & & Field & 548.5 & $476.3-638.7$ & $1.6 \pm 0.19$ & 3.2 \\
\hline \multirow[t]{4}{*}{ Spinetoram } & 2008 & Lab. & 74.8 & $58.4-95.2$ & $2.0 \pm 0.21$ & 1 \\
\hline & & Field & 175.4 & $154.8-204.4$ & $1.8 \pm 0.20$ & 2.3 \\
\hline & 2009 & Lab. & 66.7 & $51.3-84.6$ & $1.9 \pm 0.20$ & 1 \\
\hline & & Field & 176.3 & $160.5-203.2$ & $1.9 \pm 0.17$ & 2.6 \\
\hline \multirow{4}{*}{$\begin{array}{l}\text { Emamectin } \\
\text { benzoate }\end{array}$} & 2008 & Lab. & 0.023 & $0.018-0.030$ & $1.6 \pm 0.17$ & 1 \\
\hline & & Field & 0.055 & $0.047-0.065$ & $1.7 \pm 0.19$ & 2.4 \\
\hline & 2009 & Lab. & 0.021 & $0.018-0.025$ & $1.7 \pm 0.18$ & 1 \\
\hline & & Field & 0.056 & $0.047-0.067$ & $1.6 \pm 0.17$ & 2.7 \\
\hline \multirow[t]{4}{*}{ Methomyl } & 2008 & Lab. & 34.7 & $30.3-42.6$ & $2.0 \pm 0.23$ & 1 \\
\hline & & Field & 2180.7 & $1860.8-2684.7$ & $1.5 \pm 0.16$ & 62.8 \\
\hline & 2009 & Lab. & 38.4 & $31.0-47.8$ & $2.1 \pm 0.23$ & 1 \\
\hline & & Field & 2440.4 & $1820.9-3150.6$ & $1.6 \pm 0.19$ & 63.6 \\
\hline \multirow[t]{4}{*}{ Chlorpyrifos } & 2008 & Lab. & 19.6 & $16.2-24.8$ & $1.9 \pm 0.21$ & 1 \\
\hline & & Field & 859.9 & $635.6-1214.2$ & $1.6 \pm 0.18$ & 43.9 \\
\hline & 2009 & Lab. & 17.3 & $14.2-22.5$ & $1.9 \pm 0.20$ & 1 \\
\hline & & Field & 851.9 & $612.2-1211.6$ & $1.7 \pm 0.18$ & 49.2 \\
\hline \multirow[t]{4}{*}{ Esfenvalerate } & 2008 & Lab. & 3.4 & $2.5-4.5$ & $1.7 \pm 0.16$ & 1 \\
\hline & & Field & 382.3 & $332.8-446.8$ & $1.8 \pm 0.19$ & 112.4 \\
\hline & 2009 & Lab. & 3.2 & $2.5-4.1$ & $1.7 \pm 0.19$ & 1 \\
\hline & & Field & 367.3 & $311.9-437.3$ & $1.6 \pm 0.16$ & 114.8 \\
\hline \multirow[t]{4}{*}{ Lufenuron } & 2008 & Lab. & 4.9 & $3.8-6.4$ & $2.0 \pm 0.22$ & 1 \\
\hline & & Field & 40.2 & $34.4-48.0$ & $1.9 \pm 0.20$ & 8.2 \\
\hline & 2009 & Lab. & 5.4 & $4.1-7.3$ & $1.9 \pm 0.21$ & 1 \\
\hline & & Field & 45.8 & $38.4-55.2$ & $1.9 \pm 0.21$ & 8.5 \\
\hline \multirow[t]{4}{*}{ Methoxyfenozide } & 2008 & Lab. & 3.7 & $3.1-4.5$ & $2.2 \pm 0.23$ & 1 \\
\hline & & Field & 19.0 & $14.6-25.6$ & $2.3 \pm 0.24$ & 5.1 \\
\hline & 2009 & Lab. & 4.2 & $3.6-5.0$ & $2.1 \pm 0.20$ & 1 \\
\hline & & Field & 20.1 & $15.3-27.5$ & $2.2 \pm 0.23$ & 4.8 \\
\hline
\end{tabular}

Data in Table (2) showed that, the $2^{\text {nd }}$ instar larvae of the field strain demonstrated varied levels of resistance to methomyl, chlorpyrifos and esfenvalerate The resistance towards methomyl appeared to increase from 43.9-fold at 2008 to 50.8 -fold at 2009 . Toxicity tests against the $2^{\text {nd }}$ larval instar with chlorpyrifos showed that resistance levels in 2008 and 2009 cotton seasons were 27.6 and 24.7 -fold. The $2^{\text {nd }}$ instar larvae of the field strain showed the highest resistance levels against esfenvalerate with resistance ratios 76.4 and 79.2. On the other hand, the $2^{\text {nd }}$ instar larvae of field strain showed no resistance to spinosad, spinetoram and emamectin benzoate. Regarding the two IGR compounds the $2^{\text {nd }}$ instar larvae of field strain showed tolerance ratios 6.8 and 8.7 to lufenuron and 7.1 and 6.2 to methoxyfenozide at 2008 and 2009 cotton seasons, respectively.
Regarding the $4^{\text {th }}$ instar larvae (Table 3 ), the field strain exerts high resistance levels towards methomyl, chlorpyrifos and esfenvalerate. Resistance ratios in 2008 and 2009 cotton seasons were 62.8 and 63.6 towards methomyl, 43.9 and 49.2 towards chlorpyrifos and 112.4 and 114.8 towards esfenvalerate. The $4^{\text {th }}$ instar larvae of the field strain showed no resistance to spinosad, spinetoram, emamectin benzoate \& methoxyfenozide, and tolerance ratios 8.2 and 8.5 towards lufenuron in 2008 and 2009 cotton seasons.

Extensive indiscriminate use of organophosphate, pyrethroid and carbamate insecticides has led to development of resistance in CLW to all these insecticides (Attia, 1999; Abo Elghar et al., 2005). The present study revealed high levels of resistance to esfenvalerate, methomyl and chlorpyrifos in the tested field population. 
Table 4. Activity of glutathione $S$-transferases in the field and laboratory strains of cotton leafworm

\begin{tabular}{ccccc}
\hline Year & Larval instar & \multicolumn{2}{c}{ S.A (OD/hr/mg protein) \pm SD } & \multirow{2}{*}{ Lab./field ratio } \\
\cline { 3 - 4 } & & Lab. strain & Field strain & \\
\hline $\mathbf{2 0 0 8}$ & $2^{\text {nd }}$ & $1.061 \pm 0.082$ & $1.942 \pm 0.102$ & 1.83 \\
\hline $\mathbf{2 0 0 9}$ & $4^{\text {th }}$ & $1.712 \pm 0.100$ & $3.716 \pm 0.146$ & 2.17 \\
\hline & $2^{\text {nd }}$ & $1.172 \pm 0.092$ & $2.051 \pm 0.173$ & 1.75 \\
\hline & $4^{\text {th }}$ & $1.547 \pm 0.056$ & $3.403 \pm 0.089$ & 2.20 \\
\hline
\end{tabular}

Table 5. Activity of alkaline phosphatases in the field and laboratory strains of cotton leafworm

\begin{tabular}{ccccc}
\hline \multirow{2}{*}{ Year } & Larval instar & \multicolumn{2}{c}{ S.A (IU / hr / mg protein) \pm SD } & \multirow{2}{*}{ Lab./field ratio } \\
\cline { 3 - 4 } & & Lab. strain & Field strain & \\
\hline $\mathbf{2 0 0 8}$ & $2^{\text {nd }}$ & $274.8 \pm 17.3$ & $695.2 \pm 38.5$ & 2.53 \\
\hline $\mathbf{2 0 0 9}$ & $4^{\text {th }}$ & $729.4 \pm 27.6$ & $1283.7 \pm 61.6$ & 1.76 \\
\hline $2^{\text {nd }}$ & $257.2 \pm 12.9$ & $635.3 \pm 23.4$ & 2.47 \\
\hline $4^{\text {th }}$ & $688.1 \pm 31.4$ & $1121.6 \pm 73.2$ & 1.63 \\
\hline
\end{tabular}

Therefore, there is a need to test different insecticides having different modes of action. In the present study spinosad, spinetoram, emamectin benzoate and methoxyfenozide are between these insecticides. Spodoptera littoralis showed low levels of tolerance to these insecticides. Regarding spinosad, these results are in variance with Temerak (2003), who reported that, the field strain of the CLW larvae proved to be more susceptible to spinosad than the laboratory strain (resistance ratios were 0.11 and 0.04 for the $2^{\text {nd }}$ and $4^{\text {th }}$ instars, respectively). In respect with emamectin benzoate, results of this study are in accordance with Abou-Taleb et al., (2009). They reported that, the field strain showed tolerance ratios to emamectin benzoate about 3.5 for the $2^{\text {nd }}$ instar and 1.6 for the $4^{\text {th }}$ instar.

\section{Activity of GST and ALP in the laboratory and field strains of CLW:}

Observations that resistance to insecticides in insects may be attributable to enhanced GSH-dependent detoxification (Oppenoorth et al., 1979; Motoyama, 1978) have focused interest on these enzymes in insect pest strains. In the present study, the field strain showed higher GST activity. In respect with the $2^{\text {nd }}$ larval instar, the GST activities in the field strain were 1.83 and 1.75 fold compared with that of lab. strain in 2008 and 2009, respectively. Regarding the $4^{\text {th }}$ larval instar, the GST activities in the field strain were 2.17 and 2.20 -fold compared with that of lab. strain in 2008 and 2009, respectively (Table 4). These results are in agreement with that reported by Attia (1999), who reported higher GST activity in the CLW field strain compared with that of lab. strain. Also, Yu et al., (2003) reported that, detoxification enzyme activities of microsomal oxidases,
GST, and hydrolases were higher in field strains of Spodoptera frugiperda (has high resistance levels to carbamate, organophosphate and pyrethroid insecticides) than in the susceptible strain.

Phosphatases (APs) are classically described as homodimeric nonspecific metalloenzymes which catalyze phosphomonesterase reactions (Trowsdale et al., 1990). Table (5) shows that, the activities of ALP in the $2^{\text {nd }}$ instar of field strain were 2.53 and 2.47 -fold of the lab. strain in 2008 and 2009, respectively. Regarding $4^{\text {th }}$ instar, ALP activities in the field strain were 1.76 and 1.63 -fold its activity in the lab. strain in 2008 and 2009, respectively. Phosphatases have been included in the list of detoxifying enzymes of insecticides; mostly of organophosphorus (Oppenoorth, 1985), however, fenvalerate and cypermethrin resistant larvae of Helicoverpa armigera showed higher activities of esterases, phosphatases and methyl paraoxon hydrolase compared with susceptible larvae (Srinivas et al., 2003).

Finally, spinosad, spinetoram and emamectin benzoate, methoxyfenozide and lufenuron can alternate with the organophosphate, carbamate and pyrethroid insecticides to avoid increasing selection pressure of CLW populations to these insecticides.

\section{REFERENCES}

Abbott, W. S. (1925). A method for computing the effectiveness of an insecticide. J. Econ. Entomol. 18: 265267.

Abo-El-Ghar G. E., Z. A. Elbermawy, A. G. Yousef and H. K. Abd Elhady (2005). Monitoring and characterization of insecticide resistance in the cotton leafworm, Spodoptera Iittoralis (Boisd.) (Lepidoptera: Noctuidae). J. Asia-Pacific Entomol. 8: 397-41 0. 
Abo-El-Ghar, M. R., M. E. Nassar, M. R. Riskalla and S. F. Abd-El-Ghafar (1986). Rate of development of resistance and pattern of cross-resistance in fenvalerate and decamethrin-resistant strains of Spodoptera littoralis. Agricultural Research Review. 61: 141-145.

Abou-Taleb, H. K, A. S. A. Saad, H. A. Mesbah, S. M. Abdel Rahman and D. A. El-Deeb (2009). Toxicity of emamectin benzoate against laboratory and field strains of cotton leafworm with reference to its effects on the AST, ALT and ALP activity, in Proceedings of the $6^{\text {th }}$ International Symposium of Mediterranean Group on Pesticide Research (MGPR), October, 2009, Cairo, Egypt, pp. $27-$ 29.

Armstrong, R. N. (1997). Structure, catalytic mechanism, and evolution of the glutathione transferases. Chem. Res. Toxicol. 10: 2-18.

Asaoka, K. and K. Takahashi (1983). A colorimetric assay of glutathione S-transferase using O-dinitrobenzene as a substrate. J. Biochem. 94: 1683-1685.

Ascher, K. R. S., V. Melamed-Madjar, N. E. Nemny and S. Tam (1987). The effect of benzoyl-phenyl urea molting inhibitors on larvae and eggs of the European corn borer, Ostrinia nubilalis HB (Lepidoptera, Pyralidae). J. Plant Disease Protection. 94: 584-589.

Attia, M. A. M. (1999). Studies on pesticide resistance phenomenon. M.Sc Thesis, Faculty of Agriculture, University of Alexandria.

Bret, B. L., L. L. Larson, J. R. Schoonover, T. C. Sparks and G. D. Thompson (1997). Biological properties of spinosad. Down To Earth. 52: 6-13.

Bueno, A. F. and S. Freitas (2004). Effect of the insecticides abamectin and lufenuron on eggs and larvae of Chrysoperla externa under laboratory conditions. BioControl. 49: 277-283.

Canela, R., M. Balcells, L. Dalmau and J. Avilla (2000). Ovicidal, larvicidal and juvenilizing activity of a picolinephenoxyanilide against Cydia pomonella. Pest Manag. Sci. 56: 586-590.

Dgkc (1972). Empfehlugen der deutschen gesellschaft fur klinische chemie. Standard-method zur bestimmung der aktivitat der alkalischen phosphatase. Z. Klin Chem. Klin Biochem. 10: 191.

Dittrich, V. (1967). A formamidine acaricide as an ovicide for three insect species. J. Econ. Entomol. 60: 13-15.

Eldefrawi, M. E., A. Toppozada, N. Mansour and M. Zeid (1964). Toxicological studies on the Egyptian cotton leafworm, Prodenia litura. I. Susceptibility of different larval instars of Prodenia to insecticides. J. Econ. Entomol. 57: 591-593.

El-Guindy, M. A., M. M. Abdel-Sattar and A. M. El-Refai (1983). The ovicidal action on insecticides and insect growth regulator / insecticide mixtures on the egg of various ages of susceptible and diflubenzuron-resistant strains of Spodoptera littoralis Boisd. Pestic. Sci. 14: $253-$ 260.
El-Shahawi, F. I. and D. H. Al-Rajhi (2000). Initial characterization of glutathione $S$ - transferase from larval midgut of Spodoptera littoralis and its inhibition by spinosad and Beauvaria bassiana using $O$-dinitrobenzene as a substrate. J. King Saud Univ. 12: 129-142.

Finney, D. J. (1971). Probit analysis, Cambridge Univ. Press, Cambridge.

Issa, Y. H., M .E. Keddis, M. A. Abdel-Sattar, F. A. Ayad and M. A. El-Guindy (1984a). Survey of resistance to organophosphorus insecticides in field strains of the cotton leafworm during 1980-1984 cotton-growing seasons. Bulletin of the Entomological Society of Egypt, Economic Series. 14: 399-404.

Issa, Y. H., M. E. Keddis, M. A. Abdel-Sattar, F. A. Ayad and M. A. El-Guindy (1984b). Survey of resistance to pyrethroids in field strains of the cotton leafworm during 1980-1984 cotton-growing seasons. Bulletin of the Entomological Society of Egypt, Economic Series. 14: 405-411.

Listowsky, I., M. Abramovitz, H. Homma and Y. Niitsu (1998). Intracellular binding and transport of hormones and xenobiotics by glutathione S-transferase. Drug Metab. Rev. 19: 305-318.

Lowery, O. H., N. J. Rosenbourgh, A. L. Farr and R. J. Rondall (1951). Protein measurement with folin phenol reagent. J. Biol. Chem. 193: 265-275.

Mitri, S. and A. A. Kamel (1970). The ovicidal effect of certain newer insecticides on Spodoptera littoralis egg masses. J. Econ. Entomol. 63: 676-678.

Motoyama, N., A. P. Kulkarni, E. Hodgson and W. C. Dauterman (1978). Endogenous inhibitors of glutathione $S$-transferase in house flies. Pestic. Biochem. Physiol. 9: 225 .

Oppenoorth, F. J. (1985). Biochemistry and genetics of insecticide resistance, In: Comprehensive Insect Physiology, Biochemistry and Pharmacology (Kerkut, G. A. and L. I. Gilbert, eds), Pergamon Press. UK. Vol: 12, pp. 731-773.

Oppenoorth, F. J., J. T. van DorPas and N. W. H. Houx (1979). Glutathione $S$-transferase and hydrolytic activity in a tetrachlovinphos resistant strain of house fly and their influence on resistance. Pestic. Biochem. Physiol. 11: 176188.

Pinela, S., F. Budia, M. I. Schneider, A. Gobbi and E. Vinuela (2000). Biological effectiveness of spinosad and methoxyfenozide (RH-2485) IGR on Spodoptera littoralis Boisd. (Lepidoptera: Noctuidae) eggs. Boletin de Sanidad Vegetal Plagas. 26: 483-491.

Prabhaker, N., N. C. Toscano, T. J. Hennebrry, S. 1. Castle and D. Weddle (1996). Assessment of two bioassay techniques for resistance monitoring of silverleaf whitefly (Homoptera: Aleyrodidae) in California. J. Econ. Entomol. 89: 805-815. 
Renkleff, J. H., W. D. Hutchison, C. D. Campbll, P. C. Bolin and D. W. Bartels (1995). Insecticide toxicity in European corn borer (Lepidoptera: Pyralidae): Ovicidal activity and residual mortality to neonates. J. Econ. Entomol. 88: 246253.

Sherby, M. S., H. K. Abou-Taleb and N. A. Mansour (2010). Ovicidal and larvicidal activity of spinosad against Egyptian cotton leafworm. J. Pest Cont. \& Environ. Sci. (Special issue for the conference of "From Academia to Pesticide Industry"). 18: 69-81.

Srinivas, R., S. S. Udikeri, S. K. Jayalakshmi and K. Sreeramulu (2003). Identification of factors responsible for insecticide resistance in Helicoverpa armigera (Hubner). Resistant Pest Management Newsletter.13: 5964.
Temerak S. A. (2002). Historical records of field cotton leafworm (Spodoptera littoralis) resistance to conventional insecticides as influenced by the resistance programs in Egypt. Resistant Pest Management Newsletter. 12: 7-10.

Temerak, S. A. (2003). Negative Cross Resistance to Spinosad: An Interesting Observation in the Field Population of Cotton Leaf worm Larvae, Spodoptera littoralis in Egypt. Resistant Pest Management Newsletter. 13: 33-36.

Trowsdale, J., D. Martin, D. Bicknell, and I. Campbell (1990). Alkaline phosphatases. Biochem. Soc. Trans. 18: 178-180.

Wells, A. L. and G. Guyer (1962). Effects of chemicals on European corn borer eggs. J. Econ. Entomol. 55: 631-633.

Yu, S. J., S. N. Nguyen, and G.E. Abo Elghar (2003). Biochemical characteristics of insecticide resistance in the fall armyworm, Spodoptera frugiperda (J.E. Smith). Pesticide Biochemistry and Physiology 77: 1-11. 


\section{الملخص العربي}

السمية التفاضلية لبعض المبيدات الحشرية على كتل البيض ويرقات دودة ورق القطن مع تقدير نشاط إنزيمين من الإنزيمات المسؤلة عن إزالة السمية

حمدى قطب أبوطالب

القطن مستويات عالية من المقاومة لل الكلوربيريفوس والميثوميل والإسفينفاليرات مقارنة بالسلالة المعملية. بخصوص العمر الثاني كانت مستويات المقاومة التى أظهرها للميثوميل هى 43.9 و50.8 في سنة 2008 و2009، للكلوربيريفوس كانت 27.6 و 24.7 24. للإسفينفاليرات كانت 76.4 و 79.2. أما العمر الرابع فقد أظهر مستويات من المقاومة 62.8 و 63.6 للميثوميل فن سنة 2008 و و و 2009، 43.9 و 49.2 للكلوربيريفوس، 112.4 و 114.8 و 114.4 للإسفينفاليرات. من ناحية أخرى لم تظهر السلالة المعملية مستويات

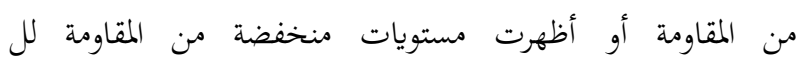

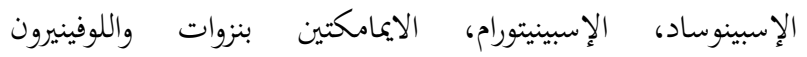

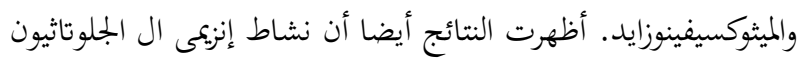
اس ترانسفيريز والالكالين فوسفاتيز كان أعلى في السلالة الحقلية

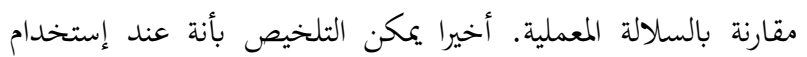

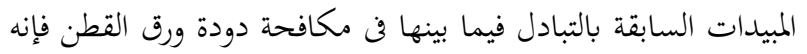
يمكن تفادى زيادة مقاومة هذه الأفة لفعل هذه المبيدات.
تم تقدير سمية بعض المبيدات الحشرية المختارة على كتل البيض و عمرين يرقيين لسلالتين من دودة ورق القطن احدهما حقلية والاخرى معملية ومقارنة نشاط انزيمي الجلوتاثيون اس ترانسفيريز والالكالين

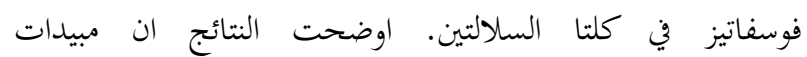

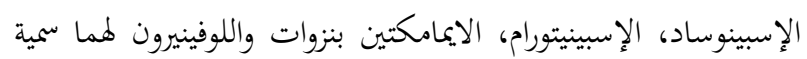
ضعيفة على البيض مقارنة بمييدات الكلوربيريفوس والميثوميل. حيث الإنين اعطى المركبين الأخيران بتركيز 10جزء في المليون نسبة موت وصلت

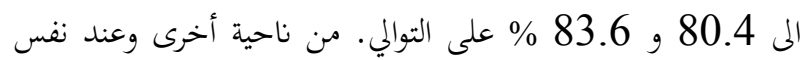

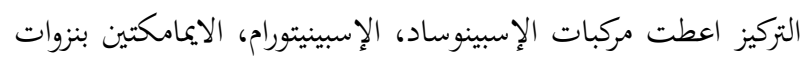
18.9، 19.4، 28.1\% موت لكتل البيض المعاملة على التوالى.

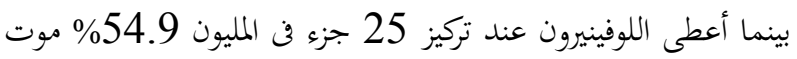
لكتل البيض المعامل، أعطى 100\% موت عند تركيز 100 جزء في عن

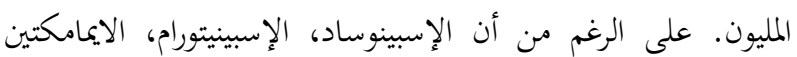

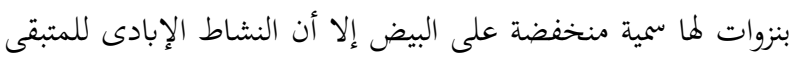

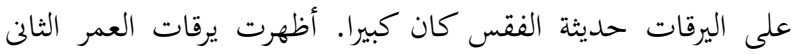

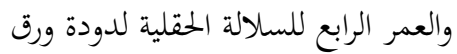

